\title{
PENGARUH POLA ASUH ORANG TUA DEMOKRATIS TERHADAP HASIL BELAJAR SISWA PADA MATA PELAJARAN MATEMATIKA KELAS VII SMPN 1 SITUBONDO
}

\section{INFLUENCE OF PARENTING PATTERN OF DEMOCRATIC PARENT TO STUDENT'S LEARNING RESULT ON MATHEMATICS SUBJECT STUDENT SMPN NEGERI 1 SITUBONDO}

\author{
Irma Noervadila \\ STKIP PGRI SITUBONDO, SITUBONDO \\ noervadilairma@gmail.com \\ Anisa Meiliana \\ STKIP PGRI SITUBONDO, SITUBONDO \\ anisavebrian1621@gmail.com
}

\begin{abstract}
ABSTRAK
Pendidikan dan pengasuhan yang benar terhadap anak akan menghasilkan efek lahirnya anak-anak yang berprestasi. Oleh karena itu, salah satu hal yang paling penting dilakukan orang tua adalah mengetahui perinsip-perinsip apa yang perluh dipegang teguh agar orang tua sukses dalam mendidik anak dan juga bagaimana metode-metode untuk sukses mendidik anak, termasuk orang tua yang hanya memiliki sedikit waktu mendidik anakanaknya.Berpijak pada permasalahn di atas, maka penulis tertarik untuk membuat judul "Pengaruh Pola Asuh Orang Tua Demokratis Terhadap hasil belajar siswa pada Mata Pelajaran matematika Kelas VIII di SMP Negeri 1 Situbondo Tahun Pelajaran 2017/2018". Permasalahan yang diangkat adalah adakah pengaruh pola asuh orang tua demokratis terhadap hasil belajar matematika siswa (kelas VIII) SMPN 1 Situbondo tahun pelajaran 2017/2018. Metode yang digunakan pada penelitian ini adalah metode kuantitatif dimana yang diteliti adalah ada atau tidak pengaruh pola asuh orang tua demokratis terhadap hasil belajar siswa. Teknik pengumpulan data melalui observasi, angket, dan dokumentasi.Hasil penelitian menunjukkan Terdapat pengaruh positif dan signifikan pola asuh orang tua demokratis terhadap hasil belajar siswa pada mata pelajaran matematika (SMP Negeri 1 Situbondo 2017/2018) yang ditunjukkan dengan harga rTabel untuk tarafsignifikansi 5\% sebesar 0,151, Harga rHitung 0,613. Jadi rHitung lebih besar dari rTabel $(0,613>0,151)$ dan nilai 0.613 dikonsultasikan dengan table interprestasi yang terletak antara 0,60-0,799 yang berarti tingkat pengaruh pola asuh orang tua demokratis terhadap hasil belajar siswa merupakan pengaruh kuat.
\end{abstract}

Kata Kunci :Pola Asuh Orang Tua Deomkratis, HasilBelajar. 


\begin{abstract}
Proper education and care for children will result in the birth effect of achieving children. Therefore, one of the most important things parents do is to know what principles need to be adhered to in order for parents to succeed in educating children and also how to successfully educate children, including parents who have little time to educate his children. Based on the problems above, the authors are interested to make the title "The Effect of Parenting Democratic Parents Against Students' Learning Outcomes in Mathematics Subject Class VIII in SMP Negeri 1 Situbondo Lesson Year 2017/2018". The issues raised are whether the influence of parenting patterns of democratic parents to the results of learning mathematics students (class VIII) SMPN 1 Situbondo academic year 2017/2018. The method used in this study is a quantitative method in which the studied is whether or not the influence of parenting patterns democratic parents to student learning outcomes. Technique of data collecting through observation, questionnaire, and documentation. The result of research indicate There is positive and significant influence of parenting pattern of democratic parent to student's learning result on mathematics subject (SMP Negeri 1 Situbondo 2017/2018) shown by rtabel price for significance $5 \%$ of 0.151 , Price $\mathrm{rH}$ calculated 0.613 . So rHitung bigger than rTabel $(0,613>0,151)$ and value 0,613 consulted with interpretation table which lies between 0,60 - 0,799 which mean level influence of parenting pattern of democratic parent toward result of student learning is strong influence.
\end{abstract}

Keywords: Deomkratis Parent's Parenting Pattern, Learning Outcomes.

\section{PENDAHULUAN}

Pendidikan memegang peranan penting untuk menjamin kelangsungan hidup bangsa dan negara. Sebagaimana telah disebutkan dalam pembukaan UUD 1945 bahwa tujuan membentuk Negara Kesatuan Republik Indonesia ialah untuk "mencedaskan kehidupan bangsa". Agar kecerdasan bangsa dapat terus berkembang maka pemerintah selalu meninjau ulang program-program pendidikan supaya dapat mengimbangi laju pertumbuhan dan perkembangan ilmu pengetahuan dan teknologi. Dengan demikian bidang pendidikan dapat menjadi salah satu pendukung dalam perwujudan tujuan pembangunan nasional.

Dalam mendukung pembangunan nasional, pendidikan hakikatnya bisa didapatkan dimana saja, baik di sekolah, di mayarakat, dan di keluarga. Akan tetapi pendidikan paling mendasar adalah pendidikan yang didapatkan anak dalam lingkungan keluarga. Keluarga merupakan lingkungan pendidikan yang pertama dan utama (Munib, 2012:72). Didalam keluarga anak pertama kali mendapatkan didikan dan bimbingan dari orangtua. Kualitas pendidikan orang tua tidak harus tergantung pada tinggi rendahnya pendidikan yang ia dapatkan akan tetapi tergantung pada tingkat semangat, motivasi, dan kesadaran orangtua terhadap pentingnya duni pendidikan pada anak.

Upaya orang tua dalam mendidik dan membimbing anak merupakan bentuk dari pola pengasuhan orang tua. Pola asuh orang tua menurut Djamarah (2014:51) 
adalah kebiasaan yang dilakukan oleh orang tua dalam memimpin, menjaga dan membimbing anak yang dilakukan secara konsisten sejak anak lahir hingga remaja dan membentuk perilaku anak sesuai dengan norma dan nilai yang baik dan sesuai dengan kehidupan masyarakat. Pola asuh merupakan intraksi anak dengan orang tua dalam mendidik, membimbing dan mendisiplinkan serta melindungi anak mencapai kedewasaan sesuai norma-norma yang ada dalam masyarakat (Edwards, 2006). Sedangkan menurut Atmosiswoyo dan Subyakto (2002), pola asuh adalah pola pengasuhan yang berlaku dalam keluarga, yaitu bagaimana keluarga membentuk perilaku generasi berikut sesuai dengan norma dan nilai yang baik dan sesuai dengan kehidupan masyarakat. Dalam pola pengasuhan, ada orang tua yang keras dalam memberikan peeraturanperaturan kepada anak, ada yang suka bermusyawarah dengan anak, bahkan ada yang memberi kebebasan penuh pada anak dalam tindakannya. Hal itu dilakukan oleh orang tua semata-mata hanya untuk kebaikan anak.

Penerapan pola asuh orang tua sangat penting karena seorang ibu merupakan lingkungan pertama dan menjadi pembentuk awal hubungan interpersonal dengan anak (Wong, 2008). Menurut Baumrind (dalam Santrock, 2007), berpendapat ada cara terbaik untuk mengasuh anak. Dia percaya bahwa orang tua tidak boleh terlalu menghukum (punitive) atau terlalu peduli (aloof). Sebaiknya orang tua menyusun aturan bagi anak dan pada saat yang sama bersifat suportif dan membimbing dan mengasuh (nurturan). Dengan memberikan pola asuh yang baik dan positif kepada anak, akan memunculkan konsep diri yang positif bagi anak dalam menilai dirinya. Menurut hidayah (2009) dimulai dari keluarga yang tidak membatasi pergaulan anak namun tetap membimbing, agar anak dapat bersikap obyektif, dan menghargai diri sendiri, dengan mencoba bergaul dengan teman yang lebih banyak. Dengan demikian pola asuh orang tua demokratis dapat dikatakan sebagai pola asuh yang baik diterapkan oleh orang tua.

Bentuk pola asuh demokratis orang tua adalah pola asuh yang mengedepankan musyawarah antara anak dan orang tua (Lestari, 2015:4). Orang tua tidak selalu memaksakan kehendaknya pada anak akan tetapi juga tidak membiarkan anak tanpa adanya kontrol. Setiap saran dan pendapat selalu dipertimbangkan sebagai pencerminan inisiatif dan kreativitas dalam mewujudkan kepentingan bersama. Menurut Munandar (1982) berpendapat pola asuh demokratis adalah cara mendidik anak, dimana orang tua menentukan peraturan-pertaturan tetapi dengan memperhatikan keadaan dan kebutuhan anak. Pola asuh demokratis adalah suatu bentuk pola asuh yang memperhatikan dan menghargai kebebasan anak, namun kebebasan itu tidak mutlak dengan bimbingan yang penuh pengertian antara orang tua dan anak (Gunarsa, 2000).Komunikasi yang terjadi antara anak dan orang tua membuat anak menjadi merasa lebih dihargai dengan dibatasi adanya aturan-aturan yang mengikatnya. Orang tua harus menyadari bahwa anak harus diberi peluang untuk melakukan eksplorasi kreatif atas ketertarikan dan bakat anak (Lestari, 2015:7). Tidak semua anak menunjukkan kecerdasan maupun ketertarikan yang sama. Oleh karena itu orang tua harus mempunyai sikap cerdas dalam rangka mengetahui minat dan bakat anak. Dengan demikian proses pencerdasan yang dilakukan mampu 
mendorong dan mengasah kapasitas anak secara optimal.

Jadi, sikap demokratis orang tua akan memberi kesempatan pada anak untuk ikut menentukan apa yang terbaik bagi dirinya disamping itu juga memberi bimbingan. Apabila anak terlanjur melakukan kesalahan, orang tua akan bersikap edukatif dibandingkan dengan memberi hukuman. Dengan demikian anak dapat mengembangkan kreatifitas serta pengetahuan untuk memperoleh hasil belajar yang optimal dalam pendidikannya.

Pola asuh orang tua kepada anak pada masa-masa remaja atau pada saat anak berada dilingkungan sekolah dapat mempengaruhi hasil belajar anak itu sendiri. Terutama ditingkat SMP pada mata pembelajaran Matematika, matematika sering dihubungkan dengan kebosanan, keengganan, kegagalan dan ketakutan bagi sebagian anak (Ahmadi dan Supriyono, 2004). Namun, matematika merupakan ilmu dasar dalam pendidikan, matematika sangat penting untuk dipelajari karena merupakan ilmu yang menjadi sumber dari semua ilmu (Adjie dan Maulana, 2006). Ssedangka menurut Jannah dkk (2013) matematika adalah sarana untuk menanamkan kebiasaan menggunakan penalaran dalam pola pikir seseorang.

Matematika berkenaan dengan ide (gagasan-gagasan), aturan-aturan, hubungan-hubungan, yang diatur secara logis sehingga matematika berkaitan dengan konsep-konsep abstrak (Wahyudi, 2012). Selanjutnya, Heruman (2007) mengemukakan matematika sebagai ilmu pengetahuan yang mempelajari struktur yang abstrak dan pola hubungan yang ada didalamnya.hal ini berarti belajar matematika pada hakekatnya adalah belajar konsep, strukur konsep, dan mencari hubungan antara konsep dan strukturnya (Widya, 2016).

Hasil belajar matematika adalah perubahan perilaku yang terjadi dalam diri siswa atau keberhasilan yang dicapai siswa setelah menerima pembelajaran matematika. Hasil belajar matematika yang diharapkan adalah hasil belajar yang memenuhi Kriteria Ketuntasan Minimum (KKM) yang telah ditetapkan oleh sekolah. Namun, dalam kenyataannya terlihat bahwa hasil belajar matematika belum sesuai dengan yang diharapkan. Berdasarkan hasil observasi kelas VIII SMP Negeri 1 Situbondo, dari 322 siswa terdapat $10 \%$ siswa yang masih memiliki nilai hasil belajar matematika yang rendah.

Melihat kenyataan di atas, dapat dikatakan bahwa peran orang tua dalam keluarga sangat penting. Sebab orang tua yang bertanggung jawab atas pendidikan anaknya. Dari latar belakang tersebut maka peneliti terdorong untuk mengadakan penelitian yang berjudul "Pengaruh Pola Asuh Orang Tua Demokratis Terhadap Hasil Belajar Matematika Siswa (Kelas VIII) SMPN 1 Situbondo Tahun Pelajaran 2017/2018". Berdasarkan latar belakang masalah di atas, maka permasalahan yang dikemukakan adalah adakah pengaruh pola asuh orang tua demokratis terhadap hasil belajar matematika siswa (kelas VIII) SMPN 1 Situbondo tahun pelajaran 2017/2018?

\section{METODE PENELITIAN}

Dalam penelitian ini menggunakan ex post facto yaitu suatu penelitian yang dilakukan untuk meneliti peristiwa yang telah terjadi dan kemudian merunut kebelakang untuk mengetahui faktorfaktor yang dapat menimbulkan kejadian tersebut. Lengkah-langkah penelitian ex post facto menurut Sukardi (2013:174) sebagai berikut: 
a. Mengidentifikasi adanya permasalahan yang signifikan untuk dipecahkan melalui metode ex post facto

b. Membatasi dan merumuskan masalah secara jelas

c. Menentukan tujuan dan manfaat penelitian

d. Melakukan study pustaka yang berkaitan dengan penelitian

e. Menentukan kerangka berfikir, pertanyaan penelitia dan hipotesis penelitian

f. Mendesain metode penelitian yang hendak digunakan termasuk dalam hal ini menentukan populasi, sampel, tehnik sampling, menentukan instrumen pengumpulan data dan analisis data

g. Mengumpulkan, mengorganisasi dan menganalisis data dengan menggunakan tehnik statistik yang relevan

h. Membuat laporan penelitian.

Penelitian ini menggunakan dua variabel yang terdiri dari pola asuh orang tua demokratis $(\mathrm{X})$ sebagai variabel bebas, dan hasil belajar (Y) sebagai variabel terikat.

Lokasi penelitian merupakan daerah yang digunakan oleh peneliti dalam melakukan suatu penelitian. Metode yang digunakan dalam penentuan lokasi peneltian yaitu purposive sampling area. Purposive sampling area adalah metode penelitian yang didasarkan atau ciri-ciri atau sifat-sifat tertentu yang dipandang mempunyai sangkut paut erat dengan ciri atau sifat populasi yang sudah diketahui sebelumnya (Sutrisno,2014:186). Lebih lanjut Arikunto berpendapat bahwa,"Purposive Sampling Area" yang bertujuan dilakukan dengan cara mengambil subyek bukan didasarkan random atau daerah tetapi didasarkan tujuan tertentu" (2013:12). Sedangkan daerah penelitian yang ditetapkan yaitu di SMP Negeri 1 Situbondo. Dalam penentuan lokasi penelitian, peneliti memiliki beberapa pertimbangan diantaranya : jumlah siswa yang cukup banyak dan latar belakang orang tua siswa yang berasal dari pedesaan, pesisir dan juga kota.

Pengertian responden menurut Sukardi (2013:15) bahwa, "responden adalah orang-orang yang dapat memberikan respon atau jawaban terhadap masalah yang diteliti”.

Penentuan responden dalam penelitian ini mengacu pada pendapat Sugiyono (2014) yang menentukan responden sesuai dengan tingkat kesalahan. Untuk mendapatkan hasil penelitian yang akurat atau tepat peneliti mengambil responden dengan tingakat kesalahan 5\%. Dikarenakan jumlah kelas VIII yang terdiri dari 10 kelas dan masingmasing kelas terdapat 32 siswa, maka jumlah responden dari populasi yang berjumlah 320 siswa untuk tingkat kesalahan 5\% adalah sebanyak 167 siswa.

Dalam penelitian ini peneliti menggunakan dua teknik pengumpulan data, yang terdiri dari :

\section{1) Observasi}

Menurut Kusumah (2010 : 66) metode obsevasi adalah proses pengambilan data dalam penelitian dimana peneliti melihat situasi penelitian. Pelaksanaan observasi dapat dilakukan dengan tiga cara;

1. Observasi langsung adalah observasi yang dilakukan oleh peneliti terhadap objek yang diteliti secara langsung (tanpa perantara)

2. Observasi tidak langsung adalah observasi yang 
dilakukan oleh peneliti terhadap suatu objek melalui perantara

3. Obseravasi partisipasi adalah observasi yang dilakukan oleh peneliti dengan cara melibatkan diri atau ikut serta dalam kegiatan yang dilaksanakn oleh individu atau sekelompok orang yang menjadi objek pengamatan.

Dalam penelitian ini, peneliti menggunakan observasi langsung untuk mengetahui data siswa dan hasil belajar siswa kelas VIII di SMP Negeri 1 Situbondo.

2) Angket atau kuisioner

Angket atau kuisioner adalah teknik pengumpulan data yang dilakukan dengan cara memberi seperangkat pertanyaan atau pernyataan tertulis kepada responden untuk dijawab. Kuisioner cocok digunakan jika jumlah responden cukup besar dan tersebar diwilayah yang luas. Kuisioner juga dapat berupa pertanyaat tertutup atau terbuka, dapat diberikan kepada responden secara langsung ataupun melalui pos dan internet.

Menurut Maman Abdurrahman (2011:45) bentuk angket dibedakan menjadi dua yaitu :

1. Angket berstruktur

Angket berstruktur adalah angket yang disusun dengan menyediakan pilihan jawaban sehingga responden hanya memberi tanda pada jawaban yang dipilih. Betuk jawaban angket berstruktur adalah tertutup artinya pada setiap item sudah tersedia berbagai alternatif jawaban.

2. Angket tidak berstruktur
Angket tidak berstruktur adalah angket yang disusun sedemikian rupa sehingga responden bebas mengemukakan pendapatnya. Bentuk jawaban angket tidak berstruktur adalah terbuka artinya setiap jawaban belum terperinci dengan jelas, kondisi ini memungkinkan jawaban responden sangat beraneka ragam atau bervariasi.

Dalam penelitian ini, peneliti menggunakan angket berstruktur. Berdasarkan penjelasan diatas penulis dalam penelitian menggunakan angket langsung yaitu responden menjawab sendiri tentang dirinya dan tertutup adalah pertanyaan atau pernyataan dengan sejumlah jawaban tertentu sebagai pilihan kepada siswa yang menjadi responden. Angket tersebut diberikan kepada responden dengan situasi tatap muka dalam suatu ruangan kelas. Metode angket pada penelitian ini sebagai metode utama dalam mengumpulkan data yang pada akhirnya akan dianalisis menuju analisa data.

3) Dokumentasi

Dokumentasi yaitu teknik pengumpulan data dengan mencatat, mengutip serta mengumpulkan data dari dokumen sekolah. Untuk memperoleh data nama-nama peserta didik yang akan menjadi responden, dan hasil belajar siswa SMP Negeri 1 Situbondo Tahun Pelajaran 2017/2018 yang dalam penelitian ini menggunakan nilai ulangan harian siswa.

\section{Analisis Deskriptif}

Menurut Sugiyono (2014:147) dalam analisis ini disusun distribusi frekuensi untuk mentabulasi data yang telah dikumpulkan yaitu dengan menyusun distribusi frekuensi dari kedua variabel 
terhadap jawaban angket yang telah diisi oleh responden. Berikut langkah langkahnya :

1. Pemberian skor

Angket yang disebarkan adalah angket langsung, tertutup dimana angket tersebut pertanyaannya yang bersifat positif sehingga skor yang digunakan adalah :

$$
\begin{array}{llr}
\text { - } & \text { Responden yang } \\
& \text { memilih jawaban selalu } \\
& \text { diberi skor } 4 \\
\text { - } & \text { Responden } \\
& \text { memilih jawaban sering } \\
& \text { diberi skor 3 } \\
\text { - } & \text { Responden } \quad \text { yang } \\
& \text { memilih jawaban } \\
& \text { jarang diberi skor } 2 \\
\text { - } & \text { Responden yang } \\
& \text { memilih jawaban tidak } \\
& \text { pernah diberi skor } 1
\end{array}
$$

2. Menentukan nilai minimum dan maksimumnya

3. Nilai rata - rata, median dan modus

4. Standart Deviasi

Uji Instrumen Penelitian

1) Uji Validitas

Uji validitas dikatakan mempunyai validitas tinggi apabila tes tersebut menjalankan fungsi ukurannya atau memberikan hasil ukuran yang tepat dan akurat. Validitas alat ukur diuji dengan menggunakan bantuan komputer program Statistical Package for the Social Sciences (SPSS) versi 17 for windows. Syarat bahwa item - item tersebut valid adalah dengan taraf signifikan $a=5 \%$, jika rhitung $>$ rtabel maka item tersebut valid.

2) Uji Reliabilitas

Uji reliabilitas menunjukkan pada suatu pengertian bahwa suatu instrument dapat dipercaya untuk digunakan sebagai alat pengumpulan data karena instrument tersebut sudah baik. Reliabilitas alat ukur dapat dipercaya apabila dalam beberapa kali pengukuran terhadap subyek yang sama diperoleh hasil relatif sama. Adapun untuk mencari reliabilitas alat ukur pada penelitian ini digunakan rumus AlphaCronbach.

Reliabilitas alat test yang juga menunjukkan derajat kekeliruan ukuran tidak dapat ditentukan dengan pasti, melainkan hanya dapat diestimasi. Teknik yang digunakan dalam menganalisis hasil validitas dan reliabilitas menggunakan bantuan komputer program Statistical Package For The Social Sciences (SPSS) versi 17 For Windows.

$$
r i=\frac{k}{(k-1)}\left\lceil 1-\frac{\sum a i^{2}}{a t^{2}}\right\rceil
$$

Keterangan :

$k=$ Jumlah item dalam instrument

$\sum a i^{2}=$ Jumlah varian skor tiap - tiap item

$a t^{2}=$ Varian total

Dalam uji persyaratan, uji yang digunakan dalam penelitian ini adalah Uji normalitas.uji normalitas digunakan untuk mengetahui apakah data berditribusi normal atau tidak. Hal ini dilakukan untuk menentukan metode statistik yang digunakan. Jika data berdistribusi normal dapat digunakan metode statistik parameterik, sedangkan jika data berdistribusi tidak normal maka dapat digunakan metode nonparameterik menurut Sugiyono yang dikutip oleh Lestari(2015).

Uji normalitas yang digunakan pada penelitian ini adalah uji normalitas dengan uji lilliefors pada taraf signifikan 5\%. Adapun kriterianya sebagai berikut:

Dalam hal ini kaidah yang digunakan adalah jika $\mathrm{p}>0,05$ maka sebaran dikatakan normal dan sebaliknya jika $\mathrm{p}<0,05$ sebaran dikatakan tidak 
normal. Untuk menguji normalitas sebaran sebagai uji persyaratan dalam penelitian ini menggunakan bantuan komputer program Statistcal Package for the Social Sciencess (SPSS) versi 17 for Windows.

Uji hipotesis yang diajukan secara untuk menjawab rumusan masalah. Pada penelitian ini digunakan analisis korelasi. Uji koefisiensi korelasi dimaksudkan agar dapat mengetahui adanya pengaruh variabel bebas terhadap variabel terikat.

$\begin{array}{rrr}\text { 1. Analisis } & \text { KorelasiProduct } \\ \text { Moment } & & \\ \text { Adapun } & \text { rumus yang } \\ \text { digunakan adalah } & & \end{array}$

$$
\begin{aligned}
& r x y \\
& =\frac{n \sum x y-\left(\sum x\right)\left(\sum y\right)}{\sqrt{\left\{n \sum x^{2}-\left(\sum x\right)^{2}\right\}\left\{n \sum y^{2}-\left(\sum y\right)^{2}\right\}}}
\end{aligned}
$$

(2014:183)

Sumber : Sugiyono

Keterangan

rxy : Koefisien Korelasi

$\sum \mathrm{X}$ : Jumlah Skor $\mathrm{X}$

$\sum \mathrm{Y}$ : Jumlah Skor Y

Hasil

perhitungan

rxydikonsultasikan pada rtabel product moment dengan taraf signifikan a $=5 \%$, jika rhitung> rTabel $\mathrm{HO}$ ditolak dan $\mathrm{Ha}$ diterima, jadi variabel bebas (Disiplin Belajar) secara simultan memiliki pengaruh nyata terhadap variabel terikat (Hasil Belajar). Dan jika rhitung < rTabel H0 diterima dan Ha ditolak, jadi variabel bebas (Disiplin Belajar) secara simultan tidak memiliki pengaruh nyata terhadap variabel terikat (Hasil Belajar).

Untuk mengidentifikasi tinggi rendahnya koefisien korelasi atau memberikan interprestasi koefisien korelasi digunakan tabel kriteria pedoman untuk koefisien korelasi sesuai dengan yang ada dalam buku Sugiyono (2014: 184).

Tabel 3.1

Pedoman interprestasi koefisiensi korelasi

\begin{tabular}{cl}
\hline Interval Koefisien & \multicolumn{1}{c}{$\begin{array}{c}\text { Tingkat } \\
\text { Hubungan }\end{array}$} \\
\hline $0,00-0,199$ & Sangat Rendah \\
\hline $0,20-0,399$ & Rendah \\
\hline $0,40-0,599$ & Sedang \\
\hline $0,60-0,799$ & Kuat \\
\hline $0,80-1,000$ & Sangat Kuat \\
\hline
\end{tabular}

Sumber : Sugiyono, 2014:184

2. Uji Signifikan Korelasi

Untuk mengetahui seberapa tingkat hubungan pola asuh orang tua terhadap hasil belajar siswa pada mata pelajaran matematika di SMPN 1Situbondo Tahun Pelajaran 2017/2018, maka dilakukan uji signifikan korelasi yaitu

$$
t=\frac{r \sqrt{n-2}}{\sqrt{1-r^{2}}}
$$

Keterangan :

$r=$ Realibilitas yang dicari

$n=$ Jumlah item pertanyaan yang diuji

Harga thitung tersebut selanjutnya dibandingkan dengan harga $t$ table.Untuk kesalahan $5 \%$ uji 2 pihak.Ketentuan bila $t$ hitung lebih kecil dari $t$ table, maka Ho diterima dan Ha ditolak. Tetapi sebaliknya bila $\mathrm{t}$ hitung lebih besar dari t tabel (th $>\mathrm{tt}$ ) maka Ha diterima. 


\section{A. Penyajian Data}

Pada bab ini penulis akan menguraikan data tentang pola asuh orang tua demokratis Data diperoleh melalui angket yang disebarkan kepada responden penelitian.Angket terdiri dari 40 item. Cara memberikan penilaian dari angket yang bersifat kualitatif menjadi data kuantitatif, maka pedoman yang digunakan adalah

- Jika responden yang memilih jawaban selalu diberi skor 4

- Jika responden yang memilih jawaban sering diberi skor 3

- Jika responden yang memilih jawaban jarang diberi skor 2

- Jika responden yang memilih jawaban tidak pernah diberi skor 1

4.1.1.2 Data hasil belajar

Data hasil belajar adalah nilai ulangan harian matematika kelas VIII SMP Negeri 1 Situbondo tahun pelajaran 2017/2018 yang diperoleh dari guru mata pelajaran matematika.

\subsection{Analisis Data}

Pada penelitian ini, peneliti melakukan sebuah penelitian di kelas VIII SMP Negeri 1 Situbondo yang terdiri dari 10 kelas. Dalam penelitian ini, peneliti menggunakan responden sebanyak 167 siswa. Dengan melihat tabel hasil angket (terlampir) peneliti dapat melakukan analisis data.

4.2.1 Uji Instrumen Penelitian

1) Uji validitas

Sebelum melakukan penelitian peneliti menguji instrumen yang akan menjadi media untuk mengumpulkan data. Uji validitas menggunakan tabel $\mathrm{r}$ poduct moment dengan $\mathrm{n}=167$ dan taraf signifikasi $5 \% \mathrm{r}_{\text {tabe }} \mathrm{l}=0,355$, dalam membuat keputuasan jika $\mathrm{r}_{\text {hitung }}>$ $\mathrm{r}_{\text {tabel }}$ valid dan jika $\mathrm{r}_{\text {hitung }}<\mathrm{r}_{\text {tabel }}$ maka tidak valid. Dari hasil uji validitas yang terdapat pada lampiran menunjukkan bahwa 31 soal dinyatak valid yaitu soal nomor $5,6,7,8,9,10,11,12,13$, $14,15,16,17,18,19,20,21,23$, $24,27,28,29,30,32,33,34,35$, $36,37,38$ dan 39 dan soal yang tidak valid yaitu soal nomor 1, 2, 3, $4,22,25,26,31$, dan 40, untuk soal yang tidak valid akan dibuang dan peneliti hanya menggunakan 31 soal yang valid untuk meneliti variabel pola asuh orang tua demokratis.

Tabel 4.3

Rangkuman uji validitas instrumen pola asuh orang tua demokratis

\begin{tabular}{cccl}
\hline $\begin{array}{c}\text { Nom } \\
\text { or } \\
\text { soal }\end{array}$ & $\begin{array}{c}\text { Rhitun } \\
\mathrm{g}\end{array}$ & $\begin{array}{c}\text { Rtab } \\
\text { el }\end{array}$ & $\begin{array}{c}\text { Interprest } \\
\text { asi }\end{array}$ \\
\hline $\begin{array}{c}\text { Item } \\
1\end{array}$ & 0,582 & $\begin{array}{c}0,35 \\
5\end{array}$ & Valid \\
\hline $\begin{array}{c}\text { Item } \\
2\end{array}$ & 0,405 & $\begin{array}{c}0,35 \\
5\end{array}$ & Valid \\
\hline $\begin{array}{c}\text { Item } \\
3\end{array}$ & 0,572 & $\begin{array}{c}0,35 \\
5\end{array}$ & Valid \\
\hline $\begin{array}{c}\text { Item } \\
4\end{array}$ & 0,385 & $\begin{array}{c}0,35 \\
5\end{array}$ & Valid \\
\hline $\begin{array}{c}\text { Item } \\
5\end{array}$ & 0,682 & $\begin{array}{c}0,35 \\
5\end{array}$ & Valid \\
\hline $\begin{array}{c}\text { Item } \\
6\end{array}$ & 0,532 & $\begin{array}{c}0,35 \\
5\end{array}$ & Valid \\
\hline $\begin{array}{c}\text { Item } \\
7\end{array}$ & 0,659 & $\begin{array}{c}0,35 \\
5\end{array}$ & Valid \\
\hline $\begin{array}{c}\text { Item } \\
8\end{array}$ & 0,716 & $\begin{array}{c}0,35 \\
5\end{array}$ & Valid \\
\hline $\begin{array}{c}\text { Item } \\
9\end{array}$ & 0,852 & $\begin{array}{c}0,35 \\
5\end{array}$ & Valid \\
\hline $\begin{array}{c}\text { Item } \\
10\end{array}$ & 0,650 & $\begin{array}{c}0,35 \\
5\end{array}$ & Valid \\
\hline Item & 0,712 & 0,35 & Valid \\
\hline
\end{tabular}




\begin{tabular}{|c|c|c|c|}
\hline 11 & & 5 & \\
\hline $\begin{array}{c}\text { Item } \\
12\end{array}$ & 0,657 & $\begin{array}{c}0,35 \\
5\end{array}$ & Valid \\
\hline $\begin{array}{c}\text { Item } \\
13\end{array}$ & 0,407 & $\begin{array}{c}0,35 \\
5\end{array}$ & Valid \\
\hline $\begin{array}{c}\text { Item } \\
14\end{array}$ & 0,771 & $\begin{array}{c}0,35 \\
5\end{array}$ & Valid \\
\hline $\begin{array}{c}\text { Item } \\
15\end{array}$ & 0,564 & $\begin{array}{c}0,35 \\
5\end{array}$ & Valid \\
\hline $\begin{array}{c}\text { Item } \\
16\end{array}$ & 0,447 & $\begin{array}{c}0,35 \\
5\end{array}$ & Valid \\
\hline $\begin{array}{c}\text { Item } \\
17\end{array}$ & 0,556 & $\begin{array}{c}0,35 \\
5\end{array}$ & Valid \\
\hline $\begin{array}{c}\text { Item } \\
18\end{array}$ & 0,428 & $\begin{array}{c}0,35 \\
5\end{array}$ & Valid \\
\hline $\begin{array}{c}\text { Item } \\
19\end{array}$ & 0,655 & $\begin{array}{c}0,35 \\
5\end{array}$ & Valid \\
\hline $\begin{array}{c}\text { Item } \\
20\end{array}$ & 0,532 & $\begin{array}{c}0,35 \\
5\end{array}$ & Valid \\
\hline $\begin{array}{c}\text { Item } \\
21\end{array}$ & 0,397 & $\begin{array}{c}0,35 \\
5\end{array}$ & Valid \\
\hline $\begin{array}{c}\text { Item } \\
22\end{array}$ & 0,503 & $\begin{array}{c}0,35 \\
5\end{array}$ & Valid \\
\hline $\begin{array}{c}\text { Item } \\
23\end{array}$ & 0,395 & $\begin{array}{c}0,35 \\
5\end{array}$ & Valid \\
\hline $\begin{array}{c}\text { Item } \\
24\end{array}$ & 0,435 & $\begin{array}{c}0,35 \\
5\end{array}$ & Valid \\
\hline $\begin{array}{c}\text { Item } \\
25\end{array}$ & 0,670 & $\begin{array}{c}0,35 \\
5\end{array}$ & Valid \\
\hline $\begin{array}{c}\text { Item } \\
26\end{array}$ & 0,529 & $\begin{array}{c}0,35 \\
5 \\
\end{array}$ & Valid \\
\hline $\begin{array}{c}\text { Item } \\
27\end{array}$ & 0,671 & $\begin{array}{c}0,35 \\
5\end{array}$ & Valid \\
\hline $\begin{array}{c}\text { Item } \\
28\end{array}$ & 0,555 & $\begin{array}{c}0,35 \\
5\end{array}$ & Valid \\
\hline $\begin{array}{c}\text { Item } \\
29\end{array}$ & 0,543 & $\begin{array}{c}0,35 \\
5\end{array}$ & Valid \\
\hline $\begin{array}{c}\text { Item } \\
30\end{array}$ & 0,612 & $\begin{array}{c}0,35 \\
5 \\
\end{array}$ & Valid \\
\hline $\begin{array}{c}\text { Item } \\
31\end{array}$ & 0,544 & $\begin{array}{c}0,35 \\
5\end{array}$ & Valid \\
\hline
\end{tabular}

Dari hasil rangkuman uji validitas diatas soal nomor 1 sampai soal nomor 31 adalah valid. Instrumen yang piling valid adalah item nomor 9 dengan nilai sebesar 0,852 dan instrumen paling rendah adalah item nomor 23 dengan nilai sebesar 0,395 . Sehingga 31 instrumen penelitian tersebut dapat digunakan lebih lanjut untuk penelitian.

2) Uji reliabilitas

Pengujian reliabilitas membandingkan rhitung dengan rtabel. Untuk rtabel menggunakan table $\mathrm{r}$ product moment dengan $\mathrm{n}=$ 167 dan taraf signifikasi 5\%. rtabel $=0,355$, dalam buat keputusan jika rhitung> rtabel maka reliable dan rhitung < rtabel maka tidak reliable. Untuk melihat hasil uji, peneliti menngunakan bantuan aplikasi Statistical Package for the Social Sciences (SPSS) versi 17 for Windows, berikut hasil dari perhitungan :

Tabel $\quad 4.4 \quad$ Uji

Reliabilitas

\begin{tabular}{|r|r|}
\multicolumn{2}{|c|}{ Reliability Statistics } \\
\hline $\begin{array}{c}\text { Cronbach's } \\
\text { Alpha }\end{array}$ & N of Items \\
\hline .930 & 31 \\
\hline
\end{tabular}

Untuk melihat hasil dari $\mathrm{r}_{\text {hitung }}$ dapat dilihat pada tabel cornbach's alpha, terdapat nilai 0,930 . Nilai tersebut merupakan nilai dari rhitung. Selanjutnya untuk mengambil keputusan kita bandingkan $r_{\text {hitung }}$ dengan $r_{\text {tabel }}$. Dari hasil perhitungan cornbach's alpha tersebut dikonsultasikan pada rtabel dengan taraf signifikasi 5\% yang besarnya rtabel $=0,355$ dan nilai 
rhitung $=0,930$ jadi rhitung lebih besardaripada $\operatorname{rtabel}(0,930>0,355)$ maka dapat dikatakan instrument tersebut reliable.

\subsubsection{Uji Persyaratan}

Dalam uji persyaratan, uji yang digunakan dalam penelitian ini adalah Uji normalitas.uji normalitas digunakan untuk mengetahui apakah data berditribusi normal atau tidak. Uji normalitas yang digunakan pada penelitian ini adalah uji normalitas dengan uji lilliefors pada taraf signifikan 5\%. Adapun kriterianya sebagai berikut:

Dalam hal ini kaidah yang digunakan adalah jika $\mathrm{p}>0,05$ maka sebaran dikatakan normal dan sebaliknya jika $\mathrm{p}<0,05$ sebaran dikatakan tidak normal. Untuk menguji normalitas sebaran sebagai uji persyaratan dalam penelitian ini menggunakan bantuan komputer program Statistcal Package for the Social Sciencess (SPSS) versi 17 for Windows.

Dalam perhitungan yang telah dilakukan oleh peneliti di dapat hasil $p$ pada pola asuh orang tua demokratis yaitu 0,442(terlampir). Berdasarkan pernyataan di atasdapat dikatakan sebaran angket sudah normal karena $\mathrm{p}>0,05$.

\subsection{Pengujian Hipotesis}

Sesuai dengan analisis data yang telah dikemukakan pada bab III. Pengumpulan data yang ditetapkan dengan menggunakan Korelasi

Product Moment. Untuk kepentingan analisis data ini dari disiplin belajar dan hasil belajar adalah sebagai berikut : $\mathrm{X}=14931$

$$
\mathrm{XY}=1212535
$$$$
X^{2}=1344565
$$

$$
\begin{aligned}
& \left(\sum \mathrm{X}\right)^{2}=222934761 \\
& \mathrm{Y}=13518 \\
& \mathrm{Y} 2=1098498 \\
& \left(\sum \mathrm{Y}\right)^{2}=182736324 \\
& \text { Tabel } 4.5 \quad \text { Hasil Uji } \\
& \text { Hipotesis }
\end{aligned}
$$

Model Summary ${ }^{b}$

\begin{tabular}{|l|r|r|r|r|}
\hline Model & \multicolumn{1}{|c|}{$\mathrm{R}$} & R Square & $\begin{array}{c}\text { Adjusted R } \\
\text { Square }\end{array}$ & $\begin{array}{r}\text { Std. Error of } \\
\text { the Estimate }\end{array}$ \\
\hline 1 & $.613^{\mathrm{a}}$ & .376 & .372 & 4.01901 \\
\hline
\end{tabular}

a. Predictors: (Constant), DEMOKRATIS

b. Dependent Variable: NILAI

Untuk mengetahui apakah hipotesis yang diajukan diterima atau ditolak, maka harga rHitung dibandingkan dengan $r$ Tabel. Hasil pengujian hipotesis selengkapnya adalah sebagai berikut:

Pada taraf signifikansi 5\% dengan sample 167 siswa diperoleh rTabel = sedangkan rHitung sebesar 0,613. Jadi, rHitung> rTabel $(0,613>0,151)$.Maka, hipotesis $\mathrm{H0}$ ditolak dan Ha diterima, jadi variabel bebas (Pola asuh orang tua

\begin{tabular}{|c|c|c|c|c|c|c|}
\hline \multicolumn{7}{|c|}{ Coefficients $^{\mathrm{a}}$} \\
\hline \multirow{2}{*}{\multicolumn{2}{|c|}{ Model }} & \multicolumn{2}{|c|}{$\begin{array}{l}\text { Unstandardized } \\
\text { Coefficients }\end{array}$} & $\begin{array}{c}\text { Standardized } \\
\text { Coefficients }\end{array}$ & \multirow[b]{2}{*}{$\mathrm{t}$} & \multirow[b]{2}{*}{ Sig. } \\
\hline & & B & Std. Error & Beta & & \\
\hline 1 & (Constant) & 44.457 & 3.676 & & 12.095 & .073 \\
\hline & $\begin{array}{l}\text { DEMOKRA } \\
\text { TIS }\end{array}$ & .408 & .041 & .613 & 9.963 & .050 \\
\hline
\end{tabular}
demokratis) secara simultan memiliki pengaruh nyata terhadap variabel terikat (Hasil Belajar).

\section{Uji Signifikan Korelasi}

Tabel 4.6 Uji

Signifikan Korelasi a. Dependent Variable: NILAI 
Harga $t_{\text {hitung }}$ tersebut selanjutnya dibandingkan dengan harga $t_{\text {table }}$. Untuk kesalahan 5\% uji 2 pihak dan dk $=167-2$ $=165$, maka diperoleh $\mathrm{t}_{\text {tabel }} 1,654$

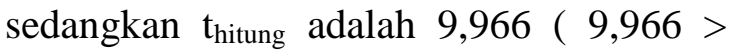
1,654 ).Dari hasil tampak bahwa $t_{\text {hitung }}$ lebih besar dari $t_{\text {tabel maka Ha }}$ diterima.Dengan demikian korelasi 0,613 itu signifikan.

\section{BAHASAN UTAMA}

Berdasarkan penelitian data angket, hasil pola asuh orang tua demokratis memiliki pengaruh yang cukup signifikan terhadap hasil belajar siswa kelas VIII SMP Negeri 1 Situbondo. Perhitungan pengujian hipotesis yang menyatakan pola asuh orang tua demokratis memiliki pengaruh terhadap hasil belajar siswa kelas VIII SMP Negeri 1 Situbondo. Hal ini diperkuat dengan adanya hasil perhitungan pada uji korelasi product moment yang diperoleh nilai sebesar 0,613. Untuk mengambil keputusan, maka harga rHitung dibandingkan dengan rTabel. Hasil pengujian hipotesis selengkapnya adalah sebagai berikut:

Pada taraf signifikansi 5\% dengan sample 167 siswa diperoleh rTabel = sedangkan rHitung sebesar 0,613. Jadi, rHitung> rTabel $(0,613>0,151)$.Maka, hipotesis $\mathrm{H0}$ ditolak dan Ha diterima, jadi variabel bebas (Pola asuh orang tua demokratis) secara simultan memiliki pengaruh nyata terhadap variabel terikat (Hasil Belajar).

Untuk mengidentifikasi tinggi
rendahnya koefisien korelasi atau
memberikan interprestasi koefisien
korelasi digunakan tabel kriteria pedoman
sebagaimana telah ditampilkan pada tabel
3.4. Untuk hasil 0,613 berada pada interval
koefisien $0,60-0,799$ dengan tingkat
hubungan yang kuat. Dalam penelitian JURNAL IKA VOL 7 No. 1 JUNI 2019 | 28 hubungan antara pola asuh orang tua dan hasil belajar siswa memiliki nilai korelasi yang positif. Hubungan dua variabel ini dapat terjadi karena adanya sebab akibat. Artinya pola asuh orang tua demokratis dapat mengakibatkan hasil belajar siswa yang baik.

Pola asuh orang tua demokratis adalah cara mendidik anak, dimana orang tua menentukan peraturan-peraturan tetapi dengan memperhatikan keadaan dan kebutuhan anak. Pola asuh orang tua demokratis adalh suatu bentuk pola asuh yang memperhatikan dan menghargai kebebasan anak, namun kebebasan itu tidak mutlak dan dengan bimbingan yang penuh pengertian antara orang tua dan anak.Dengan kata lain, pola asuh orang tua demokratis ini memberi kebebasan kepada anak untuk mengemukakan pendapat, melakukan apa yang diinginkan dengan tidak melewati batasan-batasan atau aturan-aturan yang telah ditetapkan oleh orang tua. Orang tua juga selalu memberi bimbingan dan arahan dengan penuh pengertian terhadap anak mana yang boleh dilakukan dan tidak.hal tersebut dilakukan orang tua denga lemah lembut dan penuh kasih sayang. Dalam pola asuh ini, anak tumbuh rasa tanggung jawab, mampu bertindak sesuai dengan norma yang ada.

Sedangkan hasil belajar yang telah diperoleh siswa terdapat 13 orang siswa yang memperoleh nilai diatas 90. Dari siswa-siswa tersebut nilai tertinggi adalah sebesar 99 dan nilai terkecil sebesar 75 . Dengan nilai tersebut terdapat Dari hasil belajar ada dapat diketahui bahwa pola asuh orang tua demokratis yang terima siswa dirumah dapat berpengaruh terhadap hasil bejar disekolah.

Orang tua yang menggunakan pola asuh demokratis memeiliki karakter yang penyayang, tegas, dan komunikatif. Dari 
karakter orang tua yang demikian, anak akan memeiliki perilaku yang gembira, percaya diri, memiliki rasa ingin tahu yang sehat, tidak menja, mandiri, memiliki kontrol diri yang baik, memiliki keterampilan sosial yang efektif, termotivasi, dan berprestasi disekolah.

\section{PENUTUP}

Setelah penulis menganalisis semua data yang diperoleh dari hasil penelitian tentang pengaruh pola asuh orang tua demokratis terhadap hasil belajar siswa kelas VIII SMP Negeri 1 Situbondo tahun pelajaran 2017/2018, maka penulis mengambil kesimpulan ada pengaruh pola asuh orang tua demokratis terhadap hasil belajar siswa kelas VIII SMP Negeri 1 Situbondo tahun pelajaran 2017/2018. Dari analisis data dan pengujian hipotesis, didapat tingkat pengaruh pola asuh orang tua demokratis $(\mathrm{X})$ terhadap hasil belajar siswa (Y) sebesar 0,613, dengan kata lain bahwa tingkat hubungannya bersifat kuat.

\section{Daftar Pustaka}

Abdurrahman, Maman. 2011. DasarDasar Metode Statistik Untuk Penelitian. Bandung : CV.Pustaka Setia.

Adji, Nahrowi Dan Maulana. 2006. Pemecahan Masalah Matematika. Bandung : Upi Press.

Ahmadi, Abu Dan Widodo Supriyono. 2004. Psikologi Belajar. Jakarta : PT. Asdi Mahasatya.

Annuzul, Ahmad Fauzi. 2012. Pengaruh Pola Asuh Orang Tua Terhadap Konsep Diri Positif Peserta Didik MI Tsamrotul Huda II Jatirogo Bonang Demak. Skripsi (Semarang: Fakultas Tarbiyah).

Dariyo. 2013. Pengaruh Pola Asuh Orang Tua Terhadap Kemandirian Siswa Dalam Belajar Pada Siswa Kelas XI
SMA Negeri Sumpiuh Banyumas Tahun Pelajaran 2013/2014. Skripsi (Semarang : Fakultas Ilmu Pendidikan).

Djamarah,Syaiful Bahri. 2014. Pola Asuh Orang Tua dan Komunikasi dalam Keluarga : Upaya Membangun Citra Anak. Jakarta : Rineka Cipta.

Edward. 2006. Cara Mendidik Anak. Jakarta : Salemba Medika.

Gunarsa, Singgih D. 2000. Psikologi Perkembangan Anak Dan Remaja. Jakrta : PT. Gunung Mulia.

Heruman. 2007. Model Pembelajaran Matematika Di Sekolah Dasar. Bandung : PT. Remaja Rosdakarya.

Hidayah, Rifa. 2009. Psikologi Pengasuhan Anak. UIN Malang Press (Anggota IKAPI).

Hidayat, Achmad Sholeh N. 2015. Perbedaan Hasil Pola Asuh Orang Tua Demokratis Dengan Hasil Pola Asuh Orang Tua Otoriter Terhadap Prestasi Belajar Siswa Kelas 5 SDN 2 Peleyan Tahun 2015/2016. Skripsi (Situbondo: Fakultas Keguruan Dan Ilmu Pendidikan)

Jannah, M, Triyanto. 2013. Penerapan Model Missouri Mathematic Project (MMP) Untuk Review Meningkatkan Pemahaman Dan Sikap Positif Siswa Pada Materi Fungsi, Jurnal Pendidikan Matematika Solusi Vol.1 No.1, Maret, 61-66.

Kusuma, Wijaya. 2010. Metodologi Penelitian. Jakarta : Balai Pustaka.

Latipah, Eva. 2012. Bimbingan Dan Konseling. Yogyakarta : CV.Anndi Offset.

Lestari, Fitri Puji. 2015. Pengaruh Pola Asuh Demokratis Orangtua Terhadap Hasil Belajar Pendidikan Agama Islam Siswa Kelas XI SMAN 
1 Donorojo. Skripsi (Semarang: Fakultas Ilmu Tarbiyah Dan Keguruan)

Moin, Agus Samsul. 2008. Pengaruh Pola Asuh Demokratis Orang Tua Terhadap Akhlak Anak Di Mts NU 07 Patebon Kabupaten Kendal. Skripsi (Semarang: Fakulatas Tarbiyah IAIN Walisongo).

Munandar. 1982. Pemanduan Anak Berbakat. Jakarta : Rajawali Jakarta.

Munib,Achmad.2012. Pengantar Ilmu Pendidikan.Semarang: UPT UNNES press.

Rusman. 2013. Belajar dan Pembelajaran Berbasis Komputer. Jakarta: Rajawali Pers.

Rusmono. 2012. Strategi Pembelajaran dengan Problem Based Learning Itu Perlu untuk Meningkatkan Profesionalitas Guru. Bogor : Ghalia Indonesia

Santrock, J.W. 2007. Psikologi Perkembangan. Edisi 11 Jilid 1. Jakarta : Erlangga.

Siregar, Syofiyan. 2014. Metode Penelitian Kuantitatif. Jakarta: Kencana.

Slameto. 2010. Belajar \& Faktor-Faktor Yang Mempengaruhi. Jakarta : Rineka Cipta

Sudjana, Nana. 2012. Dasar-Dasar Proses Belajar Mengajar. Bandung: Sinar Baru Algensindo.

Sugiyono. 2010. Statistik untuk penelitian. Bandung : Alfabeta.

Sugiyono. 2014. Metode penelitian pendidikan: pendekatan kuantitatif, kualitatif, dan $R \& D$. Bandung: Alfabeta.

Sukardi. 2013. Metodelogi Penelitian Pendidikan Kompetensi Dan Praktiknya. Jakarta : Bumi Aksara.
Surbakati. 2012. Keluarga Sebagai Wadah Pendidikan Utama. Jakarta : PT.Rosdakarya.

Sutrisno, Edy. 2014. Manajemen Sumber Daya Manusia. Jakarta : Pernada Media Grup

Tim penyusun Kamus Pusat Pembinaan dan Pengembangan Bahasa. 1999.Kamus Besar Bahasa Indonesia. Jakarta: Balai Pusat

Wahyudi. 2012. Matematika Realistik Dan Implementasinya Dalam Proses Pembelajaran. Bandung : Falah Production.

Widowati, S.Nurcahyani Dessy. 2013. Hubungan Antara Pola Asuh Orang Tua, Motivasi Belajar, Kedewasaan Dan Kedisiplinan Siswa Dengan Prestasi Belajar Sosiologi Siswa Kelas XI SMA Negeri 1 Sidoharjo Wonogiri. Jurnal (Surakarta: Fakultas Keguruan Dan Ilmu Pendidikan)

Widya, Satya. 2016. Peningakatan Hasil Belajar Matematika Melalui Model Pembelajaran Kooperatif Tipe Make A Mach, Vol.32 No.2, Desember, 138-143.

Wong, Donna L. 2008. Buku Ajar Keperawatan Pediatrik Volume 1 Edisi Ke 6. Jakarta : EGC.

Yuniar, Hanik Arista. 2012. Korelasi Antara Pola Asuh Islami Orang Tua Dengan Tingkat Kemandirian Siswa Kelas VII SMP Negeri 5 Blora Tahun Ajaran 2011/2012. Skripsi (Semarang: Fakultas Tarbiyah). 